\title{
The effect of 1 ppm nitrogen dioxide on bronchoalveolar lavage cells and inflammatory mediators in normal and asthmatic subjects
}

\author{
R. Jörres*, D. Nowak*, F. Grimminger**, W. Seeger**, M. Oldigs*, H. Magnussen*
}

The effect of 1 ppm nitrogen dioxide on bronchoalveolar lavage cells and inflammatory mediators in normal and asthmatic subjects. R. Jörres, D. Nowak, F. Grimminger, W. Seeger, M. Oldigs, H. Magnussen. CERS Journals Ltd 1995.

ABSTRACT: Several studies have suggested that patients with bronchial asthma are more susceptible to the potential effects of nitrogen dioxide $\left(\mathrm{NO}_{2}\right)$ than healthy subjects, with respect to airway responsiveness and lung function. We investigated whether these differences are paralleled by differences in the cellular and biochemical response within the airway lumen.

Twelve subjects with mild extrinsic asthma and eight normal subjects breathed either filtered air or $1 \mathrm{ppm} \mathrm{NO}$ in a single-blind manner during intermittent exercise for $3 \mathrm{~h}$. Bronchoscopy with bronchoalveolar lavage (BAL) was performed one hour after each exposure, and on a third day without exposure (baseline day). Prostanoids, leukotrienes and histamine were analysed in BAL fluid, and the cellular composition of BAL fluid was assessed.

In the asthmatic subjects, $\mathrm{NO}_{2}$ induced a small mean drop in forced expiratory volume in one second $\left(F_{E V}\right)$. Differential cell counts in BAL fluid did not reveal significant effects of $\mathrm{NO}_{2}$. Levels of 6-keto-prostaglandin ${ }_{1 \alpha}\left(6-\right.$ keto-PGF $\left._{1 \alpha}\right)$ were decreased, and levels of thromboxane $B_{2}\left(T_{x B}\right)$ and prostaglandin $D_{2}\left(P_{2} D_{2}\right)$ in BAL fluid were increased after $\mathrm{NO}_{2}$ compared to filtered air exposure; whereas, prostaglandin $\mathrm{E}_{2}\left(\mathrm{PGE}_{2}\right)$, prostaglandin $\mathrm{F}_{2 \alpha}\left(\mathrm{PGF}_{2 \alpha}\right)$, histamine and leukotriene levels did not change significantly. The normal subjects showed no change in lung function parameters and a small increase in $\mathrm{TxB}_{2}$ after breathing $\mathrm{NO}_{2}$.

We conclude that in subjects with mild asthma $\mathrm{NO}_{2}$ is capable of inducing an activation of cells, which is compatible with enhancement of airway inflammation, even if lung function parameters and cellular composition of BAL fluid are not markedly affected. The lower susceptibility to $\mathrm{NO}_{2}$ of normal subjects is also reflected in their lower response regarding the soluble markers of inflammation in BAL. Eur Respir J., 1995, 8, 416-424.
*Krankenhaus Grosshansdorf, Zentrum für Pneumologie und Thoraxchirurgie, LVA Freie und Hansestadt Hamburg, Grosshansdorf, Germany. **Medizinische Universitätsklinik, Giessen, Germany.

Correspondence: R. Jörres

Krankenhaus Grosshansdorf

Zentrum für Pneumologie und Thoraxchirurgie

Wöhrendamm 80

D-22927 Grosshansdorf

Federal Republic of Germany

Keywords: Air pollutants

exercise

histamine

leukotrienes

lung function

prostanoids

Received: 26 November 1993

Accepted after revision 22 December 1994

Supported by the Bundesminister für Forschung und Technologie, Bonn, Germany.
Nitrogen dioxide $\left(\mathrm{NO}_{2}\right)$ is a common environmental air pollutant and, therefore, considerable efforts have been made to study its potential hazards for the human respiratory tract.

In experimental exposures of healthy subjects, $\mathrm{NO}_{2}$ has been found to have no influence on baseline lung function [1], but to enhance airway responsiveness [1] or leave it unchanged [2]. The results of some studies suggest that subjects with bronchial asthma could be more sensitive to $\mathrm{NO}_{2}$ with respect to these functional parameters [3-5]. In bronchial asthma, airway inflammation and airway hyperresponsiveness are generally considered to be prominent features [6].

We therefore investigated whether the increased susceptibility to $\mathrm{NO}_{2}$ of asthmatic subjects, as derived from lung function studies, reflects greater inflammatory changes in bronchoalveolar lavage (BAL) cells and eicosanoid mediators compared to healthy subjects. For the experimental protocol, a short-term exposure to 1 part per million (ppm) $\mathrm{NO}_{2}$ for $3 \mathrm{~h}$ during intermittent moderate exercise was chosen. Bronchoscopy was performed $1 \mathrm{~h}$ after the end of exposure in order to detect the initial changes induced by $\mathrm{NO}_{2}$. These changes should correspond to the effects of $\mathrm{NO}_{2}$ on lung function and airway responsiveness, which have been demonstrated to occur within this period of time.

\section{Methods}

\section{Subjects}

Twelve nonsmoking subjects with bronchial asthma were enrolled into the study (table 1). Their diagnosis of mild extrinsic bronchial asthma was based on typical history and followed published criteria [7, 8]. They were free of symptoms at the time of the study. All, except 
Table 1. - Individual data of the asthmatic subjects

\begin{tabular}{|c|c|c|c|c|c|c|c|c|}
\hline $\begin{array}{l}\text { Subject } \\
\text { No. }\end{array}$ & $\begin{array}{l}\text { Sex } \\
\mathrm{M} / \mathrm{F}\end{array}$ & $\begin{array}{l}\text { Age } \\
\text { yrs }\end{array}$ & $\begin{array}{l}\text { Height } \\
\mathrm{cm}\end{array}$ & $\begin{array}{c}\mathrm{VC} \\
l\end{array}$ & $\mathrm{FEV}_{1}$ & $\begin{array}{l}\mathrm{FEV}_{1} \\
\% \text { pred* }\end{array}$ & $\underset{\mathrm{PC} 20 \mathrm{FEV}_{1}}{\mathrm{mg} \cdot \mathrm{ml}^{-1}}+$ & Therapy \\
\hline 1 & $\mathrm{~F}$ & 23 & 176 & 4.4 & 3.7 & 98 & 1.65 & $\beta_{2}$ \\
\hline 2 & $\mathrm{~F}$ & 26 & 167 & 3.7 & 3.3 & 99 & 0.073 & 0 \\
\hline 3 & $\mathrm{~F}$ & 37 & 165 & 2.9 & 2.3 & 77 & 0.65 & $\beta_{2}$ \\
\hline 4 & M & 23 & 173 & 4.4 & 3.6 & 84 & 6.4 & 0 \\
\hline 5 & M & 21 & 182 & 5.1 & 4.4 & 93 & 0.05 & $\beta_{2}$ \\
\hline 6 & M & 35 & 178 & 4.4 & 3.5 & 84 & $>8$ & 0 \\
\hline 7 & M & 26 & 188 & 5.8 & 3.9 & 81 & 0.25 & 0 \\
\hline 8 & M & 32 & 187 & 6.1 & 4.3 & 93 & 0.23 & 0 \\
\hline 9 & $\mathrm{~F}$ & 26 & 176 & 4.2 & 3.5 & 95 & 0.91 & 0 \\
\hline 10 & M & 21 & 183 & 5.0 & 4.2 & 88 & 1.0 & 0 \\
\hline 11 & M & 24 & 186 & 4.9 & 4.2 & 87 & 0.28 & $\beta_{2}$ \\
\hline 12 & M & 25 & 178 & 5.0 & 3.0 & 68 & 0.23 & $\beta_{2}$ \\
\hline Mean & - & 27 & 178 & 4.7 & 3.7 & 87 & 0.58 & - \\
\hline SD & - & 5 & 7 & 0.9 & 0.6 & 9 & 5.5 & - \\
\hline
\end{tabular}

*: predicted values according to ECSC [18]; +: airway responsiveness to methacholine (geometric mean value and standard devi-

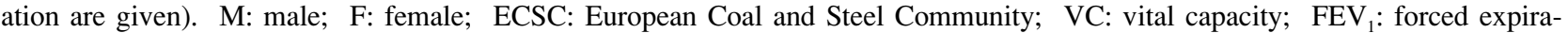
tory volume in one second; $\mathrm{PC}_{20} \mathrm{FEV}_{1}$ : provocative concentration causing a $20 \%$ decrease in $\mathrm{FEV}_{1} ; \beta_{2}$ : inhaled $\beta_{2}$-adrenoceptor agonist; 0: no medication.

one, showed airway hyperresponsiveness to inhaled methacholine as demonstrated by a provocative concentration necessary to decrease forced expiratory volume in one second $\left(\mathrm{FEV}_{1}\right)$ by $20 \%\left(\mathrm{PC}_{20} \mathrm{FEV}_{1}\right)$ of lower than $8 \mathrm{mg} \cdot \mathrm{ml}^{-1}$. Betaadrenoceptor agonists, which were inhaled by some subjects p.r.n. or regularly, were withheld for at least $8 \mathrm{~h}$ prior to each study session. None of the subjects had received inhaled corticosteroids, disodium cromoglycate or theophylline within 3 months before the study. All subjects were judged atopic on the basis of history and a positive skin-prick test to at least one common allergen (Allergopharma, Reinbek, Germany). Within 4 weeks preceding each study day, no subject suffered from an upper respiratory tract infection, experienced an uncommon burden of allergen or reported on any other trigger which may worsen asthma. Therefore, all subjects were considered to be in a stable clinical condition.

The data of the asthmatic subjects were compared with those of 8 nonsmoking healthy control subjects ( 5 females and 3 males), with mean (range) age of 27 (21-33) yrs and mean (range) $\mathrm{FEV}_{1}$ of 99 (90-112) \% of predicted. None of these subjects showed positive skin prick tests or was hyperresponsive to inhaled methacholine. Within 4 weeks preceding the study, no subject had suffered from an upper respiratory tract infection.

The study was approved by the Ethics Committee of the Medical Board of Schleswig-Holstein. All subjects were instructed about the aim of the study and gave their written informed consent.

\section{Study protocol}

Each subject was studied on three separate days, being at least one week apart, with a mean interval of 14.5 days between tests. On two of these days, subjects were exposed to $1 \mathrm{ppm} \mathrm{NO}_{2}$ or filtered air during intermittent exercise, with subsequent bronchoalveolar lavage.
Exposures started at 09:00 a.m. Subjects alternated rest for $10 \mathrm{~min}$ and exercise for $10 \mathrm{~min}$ on a bicycle ergometer whilst breathing the test gas. After each of the resting and exercise periods, lung function was measured repeatedly within $5 \mathrm{~min}$. The resting and exercise periods were repeated six times for a total of $3 \mathrm{~h}$. In addition, lung function was assessed 2, 10, 20 and $30 \mathrm{~min}$ after the end of exposure. Workload was adjusted individually to the maximum load that could be maintained during $3 \mathrm{~h}$; the same load was chosen both on the $\mathrm{NO}_{2}$ and filtered air exposure day. Bronchoscopy was performed $1 \mathrm{~h}$ after the end of exposure. Symptom scores were assessed immediately, 6 and $24 \mathrm{~h}$ after exposures.

On another day, bronchoscopy was performed at the same time of day as on the exposure days but without previous exposure to filtered air or $\mathrm{NO}_{2}$ (baseline day). The order of the three study sessions was randomized. Exposures and lung function measurements were performed single-blind, in that only the subjects were blinded. Bronchoscopy was performed without knowledge of the type of exposure, and analysis of bronchoalveolar lavage fluid (BALF) was performed entirely blind.

\section{Exposure system}

Room air was passed through particle and gas filters and a humidifier. Mean $( \pm \mathrm{SD})$ temperature was $24.6 \pm 2.9^{\circ} \mathrm{C}$ and relative humidity $68 \pm 8 \%$, with no significant differences between exposures. For $\mathrm{NO}_{2}$ exposures, 200 ppm $\mathrm{NO}_{2}$ (Linde AG, Unterschleißheim, Germany) was added to the filtered airstream, and the desired concentration of $1 \mathrm{ppm}$ was maintained within $\pm 5 \%$ by a flowregulating valve. Mixed air was sampled at the inspiratory part of the mouthpiece and $\mathrm{NO}_{2}$ was monitored continuously by a chemiluminescence nitrogen oxides analyser (Model 8840, Monitor Labs Inc., San Diego, CA, USA). The analyser was calibrated by a permeation tube 
calibrator (Model 8550, Monitor Labs Inc.) whose concentrations had been verified by an approved calibration system (Environmental Protection Agency of Hamburg, Germany).

The subjects were exposed via a mouthpiece, while sitting on a bicycle ergometer (Jaeger, Würzburg, Germany). The mouthpiece was attached to a two-way valve and an air delivery bag, the mouth part of the valve being partitioned by a separating wall. Inspiratory flow was measured by means of a pneumotachograph and electronically integrated to give tidal volume and minute ventilation (Jaeger, Würzburg, Germany). Mean expired carbon dioxide and oxygen concentrations were determined using a carbon dioxide analyser and an oxygen analyser (Jaeger, Würzburg, Germany) to aid in controlling workload. Oxygen saturation and heart rate were monitored using an ear lobe oximeter (Radiometer, Copenhagen, Denmark). Tidal volume, minute volume, temperature, humidity, and gas concentrations were recorded continuously on a tape recorder (Rikadenki Electronics, Freiburg, Germany).

\section{Lung function measurement}

Forced expiratory volume in one second $\left(\mathrm{FEV}_{1}\right)$ was determined by a pneumotachograph (Jaeger, Würzburg, Germany). All measurements were performed at least in duplicate, and for analysis the maximum value was taken [8].

\section{Assessment of symptoms}

The severity of symptoms induced by exposure was estimated from a questionnaire on an ordinal scale ranging 0-10. A panel of symptoms comprising throat irritation, cough, chest tightness, shortness of breath, headache, nausea and dizziness was checked.

\section{Fibreoptic bronchoscopy}

Bronchoscopy was performed according to the guidelines for their scientific use [9] by one investigator (D.N.) using a flexible bronchoscope (BF20-D, Olympus, Tokyo, Japan). All subjects were premedicated subcutaneously with $0.5 \mathrm{mg}$ atropine $30 \mathrm{~min}$ prior to bronchoscopy. Immediately before bronchoscopy, all subjects inhaled $0.1 \mathrm{mg}$ of fenoterol. Topical anaesthesia of the nose and pharynx was achieved by $0.5 \%$ lidocaine, and additional anaesthesia of the nose by $2 \%$ lidocaine gel. During bronchoscopy, subjects received $100 \%$ oxygen at a rate of $4 l \cdot \mathrm{min}^{-1}$ through a nasal cannula. The bronchoscope was introduced transnasally or orally, with additional $0.5 \%$ lidocaine applied through the channel to the larynx, vocal cords and trachea. Endobronchial examination was performed, and the results were summarized in macroscopic scores ranging 0-3 and comprising the variables: erythema, oedema, secretions, and friability [10]. For analysis, scores were collapsed into two categories
(0-1 vs 2-3). Local anaesthesia of the middle lobe (first and third bronchoscopy) or lingula bronchus (second bronchoscopy) was achieved, and the bronchoscope was wedged into a respective segment. BAL was performed using $5 \times 20 \mathrm{ml}$ aliquots of sterile saline at $37^{\circ} \mathrm{C}$. BALF was immediately aspirated into siliconized glassware. BALF was transported on ice to the laboratory; after initial centrifugation $\left(15 \mathrm{~min}, 4^{\circ} \mathrm{C}, 1,000 \mathrm{rpm}\right)$ cells were transferred to the cytocentrifuge, and the supernatant was further processed on extraction columns. Immediately before and after, and 2-3 $\mathrm{h}$ after bronchoscopy, $\mathrm{FEV}_{1}$ was determined by means of a wedge spirometer.

\section{Analytical procedures}

The analytical procedures followed the same protocol as described previously [11]. We determined leukotrienes (LT) $\mathrm{C}_{4}, \mathrm{D}_{4}, \mathrm{E}_{4}$ and $\mathrm{B}_{4}$, and their $\omega$-oxidation products 20-OH-LTB ${ }_{4}$ and 20-COOH-LTB ${ }_{4}$, which were extracted from BALF by solid-phase extraction columns immediately after removal of cells [12]. Nonmethylated compounds were analysed by reverse-phase (RP)-high performance liquid chromatography (HPLC) [13]. Full spectra $(190-600 \mathrm{~nm})$ of eluting compounds allowed correction to be made for possible coeluting material, and further verification was achieved by analysing sampled fractions by post-HPLC radioimmunoassays with anti$\mathrm{LTC}_{4}$ and anti-LTB $\mathrm{LT}_{4}[13]$. RP-HPLC of methylated compounds was performed by isocratic elution and a subsequent linear gradient [11], and straight phase HPLC as a modification of the method of POwELL [14]. All data were corrected for recoveries of the overall analytical procedure by the addition of $0.125 \mu \mathrm{Ci}$ of $\left({ }^{3} \mathrm{H}\right) \mathrm{LTC}_{4}$ and 0.05 $\mu \mathrm{Ci}$ of $\left({ }^{3} \mathrm{H}\right) \mathrm{LTB}_{4}$ as internal standards in each lavage sample. Recoveries were between 25 and 55\%, and detection limits between 0.6 and $0.8 \mathrm{ng} \cdot \mathrm{ml}^{-1}$.

Histamine in BALF was analysed by means of a solid phase radioimmunoassay ( $\mathrm{J}-125$, Biermann Diagnostica, Bad Nauheim, Germany).

The levels of prostaglandin (PG) $\mathrm{D}_{2}, \mathrm{E}_{2}$ and $\mathrm{F}_{2 \alpha}$ in BALF were assessed by commercially available radioimmunoassay kits (Amersham, Braunschweig, Germany). Thromboxane $\mathrm{B}_{2}\left(\mathrm{TxB}_{2}\right)$ and 6-keto-PGF $\mathrm{F}_{1 \alpha}$ were determined by custom radioimmunoassays [15].

\section{Analysis of BAL cells}

Cytological examination of 500 BAL cells was carried out on cytocentrifuge slides, which had been stained according to May-Grünwald-Giemsa.

\section{Statistical evaluation}

The effects of exposures to $\mathrm{NO}_{2}$ and filtered air were expressed as percentage changes from baseline values. Mean values and standard deviations (SD) or standard errors of the mean (SEM) were computed for lung function and exercise parameters. For BALF data, median 
values and interquartile (25-75\%) ranges were calculated. Analysis of variance (ANOVA) and post hoc paired t-tests [16] were used to evaluate the changes in lung function parameters during exposures. Group mean values were compared using the independent t-test. In the analysis of BALF data, nonparametric test procedures were applied, in order to reduce the assumptions on data distribution; the Wilcoxon matched-pairs signed-rank test was used to compare exposures within groups and the Mann-Whitney-U-test to compare the groups of healthy and asthmatic subjects with each other [17]. Correlation analysis was performed by Pearson's linear correlation, and by Spearman's rank correlation, if lavage parameters were involved [17]. For analysis of macroscopic scores and for comparison of leukotrienes, Chi-squared contingency table analysis and Fisher's exact test were used [17]. The results of macroscopic scores are presented as mean values. The level of statistical significance was assumed at $\mathrm{p}=0.05$ for each single test, and $\mathrm{p}$-values are given explicitely.

\section{Results}

\section{Experimental conditions}

During intermittent exercise, minute ventilation and heart rate did not differ significantly between exposures, with mean $( \pm \mathrm{SD})$ values of $34.4 \pm 4.7 \mathrm{l} \cdot \mathrm{min}^{-1}$ and $134 \pm 13$ beats $\cdot \mathrm{min}^{-1}$ with filtered air, and $34.5 \pm 6.0 \mathrm{l} \cdot \mathrm{min}^{-1}$ and $135 \pm 14$ beats $\cdot \mathrm{min}^{-1}$ with $\mathrm{NO}_{2}$. Similarly, these parameters did not show significant differences between the asthmatic and healthy group.

\section{Lung function and symptoms}

The asthmatic subjects showed mean $\left( \pm\right.$ SEM) $\mathrm{FEV}_{1}$ of $3.57 \pm 0.16$ and $3.58 \pm 0.12 l$ before and immediately after breathing filtered air, and $3.51 \pm 0.14$ and $3.46 \pm 0.13 l$ before and immediately after $\mathrm{NO}_{2}$ exposure (fig. 1). Whereas baseline values did not differ statistically, the mean percentage fall during $\mathrm{NO}_{2}$ exposure $(2.5 \%)$ was significantly greater than during filtered air exposure $(1.3 \%)(\mathrm{p}=0.011$, ANOVA). This difference was mainly due to subject no. 7, who showed a fall of $\mathrm{FEV}_{1}$ of $20 \%$ during breathing $\mathrm{NO}_{2}$ and an improvement of $6 \%$ during breathing filtered air; and to subject No. 12 who showed an improvement of $6 \%$ during filtered air and no change during $\mathrm{NO}_{2}$ exposure.

After the first but not after the following five exercise periods, significant exercise-induced bronchoconstriction occurred ( $\mathrm{p}=0.007$, paired t-test); there was no difference between $\mathrm{NO}_{2}$ and filtered air results.

In the healthy subjects mean ( \pm SEM) $\mathrm{FEV}_{1}$ was $3.98 \pm 0.15$ and $4.07 \pm 0.16 l$ before and immediately after exposure to filtered air, respectively, and $4.03 \pm 0.19$ and $4.07 \pm 0.17 l$ before and immediately after breathing $\mathrm{NO}_{2}$, respectively (fig. 1). Neither the $\mathrm{FEV}_{1}$ values before exposures nor the values during and after exposures were statistically different from each other.

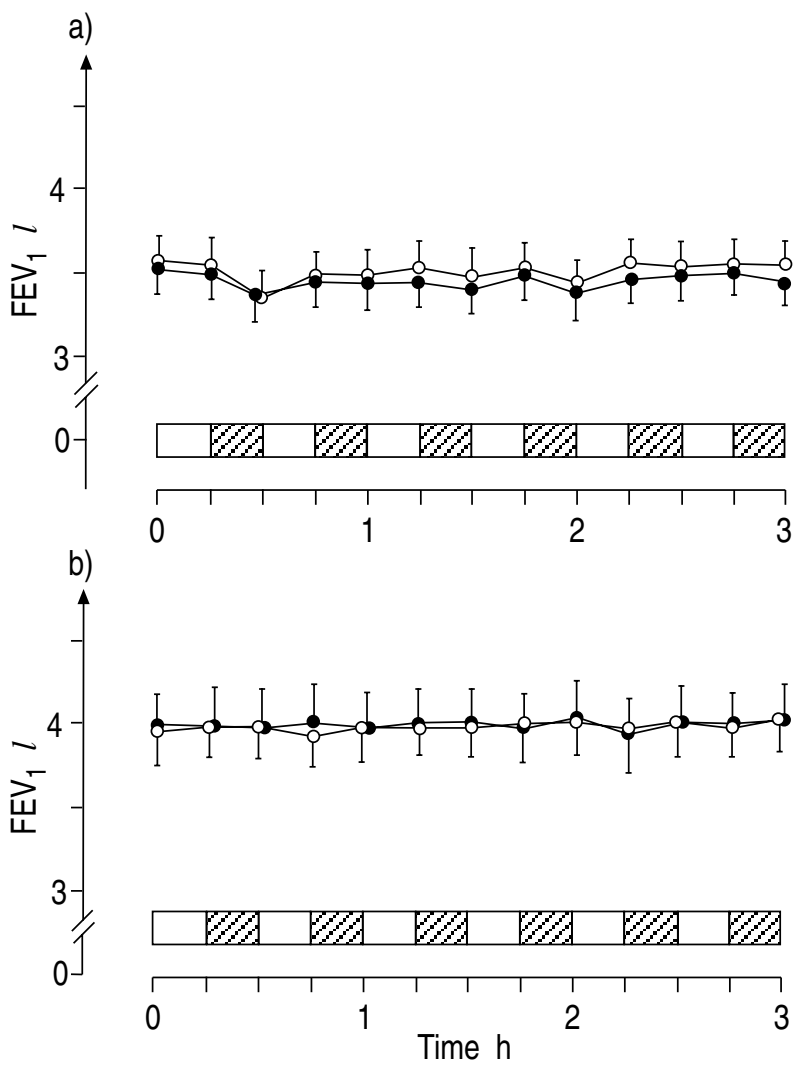

Fig. 1. - Mean ( \pm SEM) $\mathrm{FEV}_{1}$ before, during and after exposure to filtered air $(-\bigcirc)$ ) and $\mathrm{NO}_{2}(\bullet-)$ ) after periods of rest and exercise (shaded area): a) in the asthmatic patients; b) in the healthy subjects. $\mathrm{FEV}_{1}$ : forced expiratory volume in one second.

Neither the healthy nor the asthmatic subjects reported on symptoms immediately after, and 6 and $24 \mathrm{~h}$ after $\mathrm{NO}_{2}$ or filtered air exposure that were significantly different.

\section{Bronchoscopy}

Bronchoscopy on the baseline day and after exposure to filtered air or $\mathrm{NO}_{2}$ was well-tolerated, both in the asthmatic and healthy subjects. In none was therapeutic intervention necessary. In the asthmatic subjects, mean vital capacity and $\mathrm{FEV}_{1}$ after bronchoscopy dropped on average by $4.1 \%$ (maximum 16) and $2.5 \%$ (maximum 14), respectively, and in the healthy subjects by $5.0 \%$ (maximum 13) and 5.9\% (maximum 16), respectively, as compared to baseline.

\section{Macroscopic scores}

In the asthmatic subjects, the macroscopic scores of endobronchial appearance after $\mathrm{NO}_{2}$ exposure were significantly $(\mathrm{p}<0.05$ each) higher for erythema (1.2 vs 0.6 and 0.3 ), oedema ( 1 vs 0.3 and 0.6$)$, and friability $(0.6$ vs 0.2 and 0.3 ) compared to filtered air exposure and baseline bronchoscopy, respectively. Secretion was higher $(\mathrm{p}<0.05)$ after both exposures compared to baseline bronchoscopy (1.7 vs 1.1 and 0.6). The healthy subjects did not show significant differences between bronchoscopies. 
Table 2. - Median values and interquartile range of cell numbers in BALF of the asthmatic subjects and the healthy subjects

\begin{tabular}{|c|c|c|c|c|c|c|}
\hline & \multicolumn{2}{|c|}{ Baseline day } & \multicolumn{2}{|c|}{ Filtered air } & \multicolumn{2}{|r|}{$\mathrm{NO}_{2}$} \\
\hline \multicolumn{7}{|c|}{ Bronchoalveolar lavage fluid of asthmatic patients } \\
\hline Recovery ml & 72 & $(64-75)$ & 61 & $(55-68)$ & 69 & $(57-72)$ \\
\hline Total cell number $\times 10^{6}$ & 5.5 & $(3.8-9.0)$ & 4.3 & $(2.3-6.1)$ & 4.0 & $(2.6-6.0)$ \\
\hline Macrophages \% & 89.3 & $(87.7-92.2)$ & 93.2 & $(89.1-95.3)$ & 92.4 & $(84.9-95.2)$ \\
\hline Lymphocytes \% & 3.1 & $(1.35-6.0)$ & 4.0 & $(1.85-5.55)$ & 2.85 & $(1.75-6.0)$ \\
\hline Neutrophils \% & 0.15 & $(0.0-1.15)$ & 0.5 & $(0.25-0.75)$ & 0.4 & $(0.3-0.7)$ \\
\hline Eosinophils \% & 1.0 & $(0.4-1.45)^{\dagger}$ & 0.3 & $(0.2-0.55)^{*}$ & 0.3 & $(0.0-0.95)^{*}$ \\
\hline Epithelial cells \% & 3.15 & $(1.5-5.9)$ & 1.0 & $(0.75-3.3)$ & 2.35 & $(1.4-7.95)$ \\
\hline Mast cells \% & 0.0 & $(0.0-0.0)$ & 0.0 & $(0.0-0.0)$ & 0.0 & $(0.0-0.0)$ \\
\hline \multicolumn{7}{|c|}{ Bronchoalveolar lavage fluid of healthy subjects } \\
\hline Recovery ml & 70 & $(67-78)$ & 71 & $(67-80)$ & 70 & $(63-77)$ \\
\hline Total cell number $\times 10^{6}$ & 5.5 & $(3.0-9.0)$ & 5.6 & $(3.9-8.4)$ & 4.9 & $(4.4-7.8)$ \\
\hline Macrophages \% & 94.0 & (89.3-95.0) & 93.1 & $(92.0-94.2)$ & 92.1 & $(88.4-95)$ \\
\hline Lymphocytes \% & 3.0 & $(1.9-5.8)$ & 3.35 & $(2.8-5.35)$ & 3.75 & $(2.9-5.85)$ \\
\hline Neutrophils \% & 0.8 & $(0.6-1.0)$ & 0.55 & $(0.15-0.8)$ & 0.7 & $(0.25-1.1)$ \\
\hline Eosinophils \% & 0.0 & $(0.0-0.3)^{\dagger}$ & 0.0 & $(0.0-0.3)$ & 0.1 & $(0.0-0.5)$ \\
\hline Epithelial cells \% & 1.6 & $(0.0-3.8)$ & 1.65 & $(0.75-2.7)$ & 2.1 & $(1.25-3.25)$ \\
\hline Mast cells \% & 0.0 & $(0.0-0.2)$ & 0.0 & $(0.0-0.0)$ & 0.0 & $(0.0-0.25)$ \\
\hline
\end{tabular}

BALF: bronchoalveolar lavage fluid. $\quad$ : significantly different $(\mathrm{p}<0.002)$ asthmatic $v s$ healthy. *: significantly different $(\mathrm{p}<0.05)$ from baseline.

\section{Cells in bronchoalveolar lavage fluid}

On the baseline day, the number of eosinophils in BALF was significantly greater in the asthmatic than in the healthy subjects $(\mathrm{p}=0.002)$, (table 2). Similarly, the absolute number of eosinophils from peripheral blood was increased in the asthmatic subjects $(\mathrm{p}=0.009)$.

The asthmatic subjects showed no significant differences between the three bronchoscopies with respect to BAL cell counts of macrophages, lymphocytes, neu- trophils, epithelial cells and mast cells. However, the number of eosinophils was significantly reduced after breathing filtered air $(\mathrm{p}=0.005)$ or $\mathrm{NO}_{2}(\mathrm{p}=0.03)$, as compared to baseline lavage (table 2).

In the healthy subjects, the differential cell numbers in BALF did not differ significantly between the baseline lavage and the lavages performed after exposure to filtered air or $\mathrm{NO}_{2}$ (table 2).

Recovery and total number of BAL cells did not differ between lavages for both groups (table 2).

Table 3. - Median values and interquartile range of mediators in BALF in the asthmatic subjects and the healthy subjects.

\begin{tabular}{|c|c|c|c|c|c|c|}
\hline Parameter & \multicolumn{2}{|c|}{ Baseline day } & \multicolumn{2}{|c|}{ Filtered air } & \multicolumn{2}{|r|}{$\mathrm{NO}_{2}$} \\
\hline \multicolumn{7}{|c|}{ Bronchoalveolar lavage fluid of asthmatic patients } \\
\hline 6-keto-PGF ${ }_{1 \alpha}$ & 93.1 & $(64.3-136.6)$ & 97.9 & $(89.5-106.8)$ & 65.5 & $(0.0-73.5)^{*+}$ \\
\hline $\mathrm{PGE}_{2} \quad \mathrm{pg} \cdot \mathrm{ml}^{-1}$ & 34.0 & $(20.3-46.6)^{\dagger}$ & 29.1 & $(16.7-44.7)$ & 22.2 & $(0.0-36.9)$ \\
\hline $\mathrm{pg} \cdot \mathrm{ml}^{-1}$ & 52.2 & (39.6-75.6) & 55.6 & $(46.1-66.4)$ & 75.6 & $(61.5-120.9)^{+}$ \\
\hline $\mathrm{pg} \cdot \mathrm{ml}^{-1}$ & 20.5 & $(0.0-31.8)^{\dagger}$ & 17.3 & $(0.0-26.3)$ & 15.0 & $(0.0-20.3)$ \\
\hline $\mathrm{pg} \cdot \mathrm{ml}^{-1}$ & 145.6 & $(100.5-184.5)$ & 120.5 & $(90.8-187.3)$ & 189.2 & $(147.6-227.5)^{+}$ \\
\hline Histamine $\mathrm{nmol} \cdot l^{-1}$ & 1.55 & $(0.76-6.32)$ & 3.20 & $(1.57-5.75)$ & 2.93 & $(1.50-5.88)$ \\
\hline $\mathrm{ng} \cdot \mathrm{ml}^{-1}$ & 0.0 & $(0.0-1.12)$ & 0.0 & $(0.0-0.0)$ & 1.06 & $(0.0-1.54)^{*}$ \\
\hline $20-\mathrm{OH}-\mathrm{LTB}_{4} \quad \mathrm{ng} \cdot \mathrm{ml}^{-1}$ & 0.0 & $(0.0-1.08)$ & 0.0 & $(0.0-1.79)$ & 1.68 & $(0.0-2.01)^{*}$ \\
\hline $20-\mathrm{COOH}-\mathrm{LTB}_{4} \quad \mathrm{ng} \cdot \mathrm{ml}^{-1}$ & 0.0 & $(0.0-0.0)$ & 0.0 & $(0.0-0.0)$ & 0.0 & $(0.0-1.17)$ \\
\hline $\mathrm{ng} \cdot \mathrm{ml}^{-1}$ & 0.0 & $(0.0-0.0)$ & 0.0 & $(0.0-0.0)$ & 0.0 & $(0.0-0.0)$ \\
\hline $\mathrm{ng} \cdot \mathrm{ml}^{-1}$ & 0.0 & $(0.0-0.0)$ & 0.0 & $(0.0-0.0)$ & 0.0 & $(0.0-0.65)$ \\
\hline $\mathrm{ng} \cdot \mathrm{ml}^{-1}$ & 0.0 & $(0.0-0.0)$ & 0.0 & $(0.0-0.0)$ & 0.0 & $(0.0-0.73)$ \\
\hline \multicolumn{7}{|c|}{ Bronchoalveolar lavage fluid of healthy subjects } \\
\hline 6-keto-PGF $1 \alpha$ & 88.2 & $(55.7-127.9)$ & 98.1 & $(52.3-139.1)$ & 73.4 & $(54.3-93.6)$ \\
\hline $\mathrm{pg} \cdot \mathrm{ml}^{-1}$ & 18.8 & $(0.0-27.7)^{\dagger}$ & 14.3 & $(0.0-24.3)$ & 8.6 & $(0.0-21.8)$ \\
\hline $\mathrm{pg} \cdot \mathrm{ml}^{-1}$ & 34.1 & $(30.2-70.7)$ & 33.0 & $(20.6-67.5)$ & 35.3 & $(20.5-66.3)$ \\
\hline $\mathrm{pg} \cdot \mathrm{ml}^{-1}$ & 0.0 & $(0.0-0.0)^{\dagger}$ & 0.0 & $(0.0-0.0)$ & 0.0 & $(0.0-0.0)$ \\
\hline $\mathrm{pg} \cdot \mathrm{ml}^{-1}$ & 90.4 & $(80.3-127.3)$ & 84.0 & $(71.7-107.1)$ & 119.7 & $(90.6-156.5)^{*+}$ \\
\hline Histamine $\quad \mathrm{nmol} \cdot l^{-1}$ & 0.51 & $(0.18-2.10)$ & 0.33 & $(0.15-0.68)$ & 0.29 & $(0.18-0.70)$ \\
\hline
\end{tabular}

PG: prostaglandin; $\mathrm{TxB}_{2}$ : thromboxane $\mathrm{B}_{2}$; LT: leukotriene; BALF: bronchoalveolar lavage fluid. ${ }^{\dagger}$ : significantly different $(\mathrm{p}<0.05)$ asthmatic $v s$ healthy. $*$ : significantly different $(\mathrm{p}<0.05)$ from baseline day; +: significantly different $(\mathrm{p}<0.05)$ from filtered air exposure. Leukotrienes are not shown for healthy subjects, since they did not exceed detection limits in any of the measurements. 

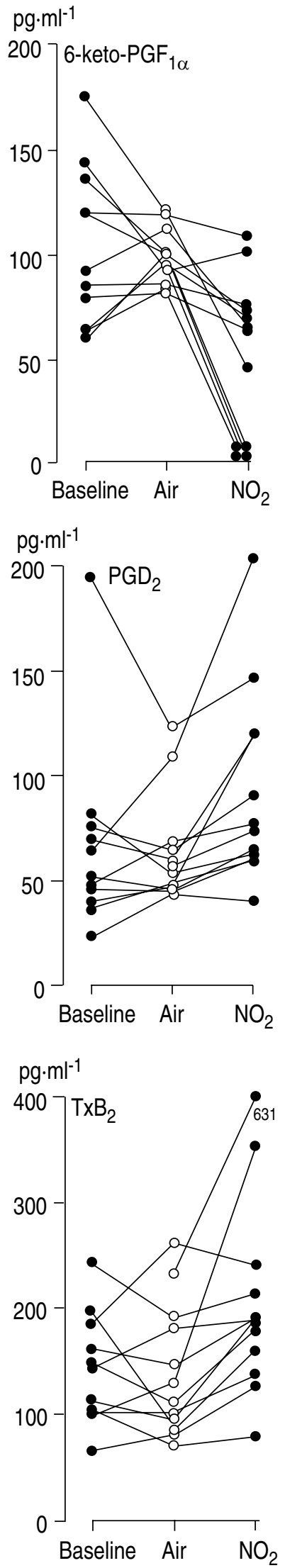

$\mathrm{pg} \cdot \mathrm{ml}^{-1}$

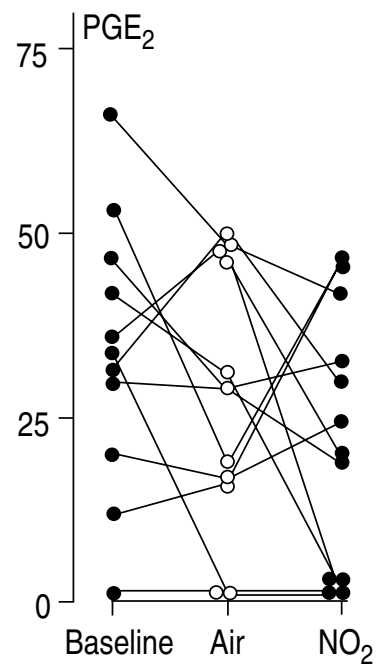

$\mathrm{pg} \cdot \mathrm{ml}^{-1}$

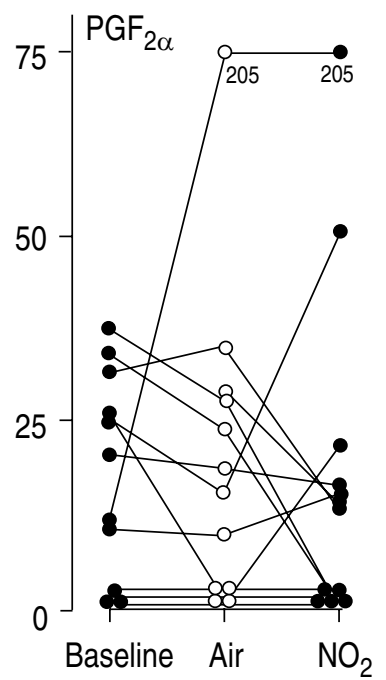

$\mathrm{nmol} \cdot l^{-1}$

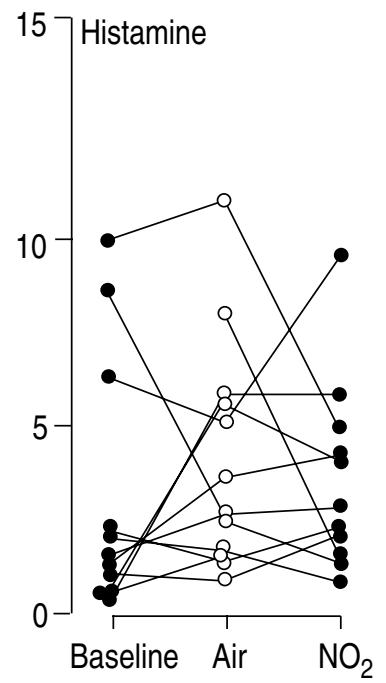

Fig. 2. - Concentrations of prostanoids and histamine in BALF after exposure to filtered air or $\mathrm{NO}_{2}$, and on the baseline day. BALF: bronchoalveolar lavage fluid; PG: prostaglandin; $\mathrm{TxB}_{2}$ : thromboxane $\mathrm{B}_{2}$. Data are given for subjects with asthma.

Mediators in bronchoalveolar lavage fluid

In baseline lavages, the levels of $\mathrm{PGF}_{2 \alpha}(\mathrm{p}=0.011)$ and $\mathrm{PGE}_{2}(\mathrm{p}=0.033)$ were significantly greater in the asthmatic subjects compared to the healthy subjects, whereas the concentration of 6-keto- $\mathrm{PGF}_{1 \alpha}, \mathrm{TxB}_{2}(\mathrm{p}=0.052)$, $\mathrm{PGD}_{2}$, and histamine $(\mathrm{p}=0.11)$ in baseline lavages did not differ statistically between groups (table 3 ). The levels of $\mathrm{LTC}_{4}, \mathrm{D}_{4}$ and $\mathrm{E}_{4}$ in baseline lavages did not differ statistically between groups. Similarly, $\mathrm{LTB}_{4}$ and its metabolites $20-\mathrm{OH}-\mathrm{LTB}_{4}$ and $20-\mathrm{COOH}-\mathrm{LTB}_{4}$ were not more often detectable in the asthmatic subjects $(\mathrm{p}=0.051)$.

The asthmatic subjects showed no significant differences in $\mathrm{PGF}_{2 \alpha}, \mathrm{PGE}_{2}$ and histamine between baseline lavage and lavages performed after $\mathrm{NO}_{2}$ or filtered air exposure. However, the levels of $\mathrm{TxB}_{2}(\mathrm{p}=0.0047)$ and $\mathrm{PGD}_{2}(\mathrm{p}=0.003)$ were significantly increased, and that of 6-keto-PGF ${ }_{1 \alpha}(\mathrm{p}=0.0029)$ decreased, after $\mathrm{NO}_{2}$ compared to filtered air exposure (table 3 and fig. 2). Compared to baseline lavages, the respective p-values were 0.051 , 0.08 and 0.0044 .

No significant differences were found in $\mathrm{LTC}_{4}, 20$ $\mathrm{COOH}-\mathrm{LTB}_{4}, \mathrm{LTD}_{4}$ and $\mathrm{LTE}_{4}$ in the asthmatic subjects (table 3 and fig. 3). The levels of $\mathrm{LTB}_{4}(\mathrm{p}=0.028)$ and $20-\mathrm{OH}-\mathrm{LTB}_{4}(\mathrm{p}=0.036)$ after $\mathrm{NO}_{2}$ exposure were significantly increased compared to baseline lavages; compared with filtered air exposure, differences were not significant (table 3). In the majority of subjects, leukotrienes were below detection limits. However, an occasional increase in $\mathrm{LTC}_{4}, \mathrm{D}_{4}$ and $\mathrm{E}_{4}$ was observed after $\mathrm{NO}_{2}$ exposure (fig. 3).

The healthy subjects showed no significant changes in prostaglandin and histamine levels between baseline lavage and lavages after $\mathrm{NO}_{2}$ or filtered air exposure (table 3 ). $\mathrm{TxB}_{2}$ concentration after $\mathrm{NO}_{2}$ exposure was significantly higher than after filtered air exposure $(\mathrm{p}=0.017)$, or in baseline lavage $(p=0.04)$. None of the leukotrienes in BALF exceeded detection limits.

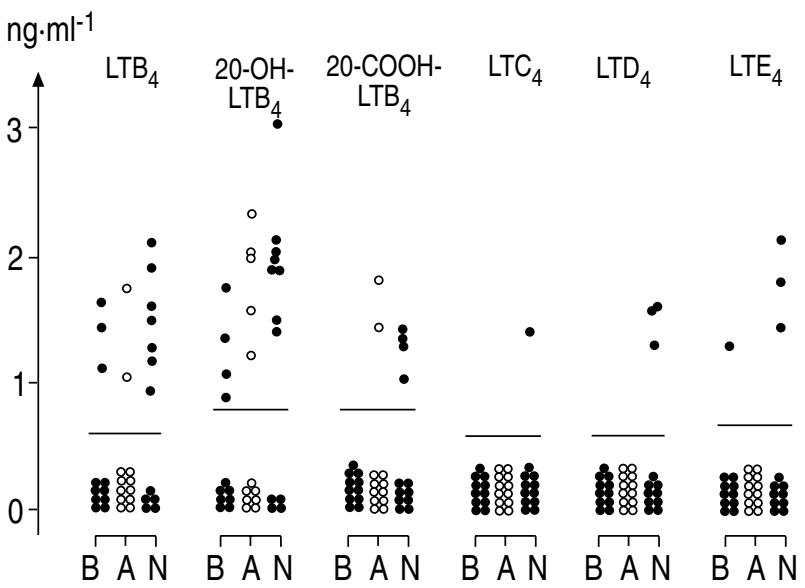

Fig. 3. - Concentrations of leukotrienes (LT) in BALF after exposure to filtered air (A) or nitrogen dioxide $(\mathrm{N})$, and on the baseline day (B). BALF: bronchoalveolar lavage fluid. Data refer to the subjects with asthma. Bars indicate detection levels. 


\section{Correlation analysis}

In the asthmatic subjects, no significant relationships were found between BAL cell counts and baseline FEV, as percentage of predicted values, or between BAL cell counts and baseline airway responsiveness to methacholine as expressed by $\mathrm{PC}_{20} \mathrm{FEV}_{1}$.

In addition, no statistically significant correlations were observed between the differences of lung function response and the differences of absolute levels of mediators in BALF between both exposures. For 6-keto-PGF ${ }_{1 \alpha}$ vs $\mathrm{PGD}_{2}\left(\mathrm{r}_{\mathrm{s}}=-0.67\right)$ as well as for $\mathrm{TxB}_{2}$ vs $\mathrm{PGD}_{2}\left(\mathrm{r}_{\mathrm{s}}=0.52\right)$, there were statistically significant $(\mathrm{p}<0.05)$ correlations between the respective percentage differences of $\mathrm{NO}_{2}$ and filtered air exposure.

\section{Discussion}

In this study, we have demonstrated that in subjects with mild bronchial asthma, short-term exposure to $\mathrm{NO}_{2}$ produces changes in prostanoid mediator profile in BALF which are indicative of cell activation within the airways. These changes were accompanied by a borderline impairment of lung function. Differential cell counts in BALF were not significantly affected. The changes in BALF after $\mathrm{NO}_{2}$ exposure were less pronounced in healthy subjects.

We have not observed marked impairment in lung function or respiratory complaints after exposure to $1 \mathrm{ppm}$ $\mathrm{NO}_{2}$, which is in accordance with the literature [18, 19]. Most of the studies suggest that the adverse functional consequences of $\mathrm{NO}_{2}$ exposure in asthmatic subjects are better assessed by measuring airway responsiveness to bronchoconstrictive stimuli [3-5, 20-23]. However, some studies were unable to demonstrate effects of $\mathrm{NO}_{2}$ on airway responsiveness [2, 18, 24, 25] at low concentrations of $\mathrm{NO}_{2}$. We did not measure airway responsiveness, because, in a previous study, we had found an increase in the amount of $\mathrm{LTB}_{4}$, its $\omega$-oxidation products, and $\mathrm{PGD}_{2}$ after methacholine inhalation in asthmatic subjects [11]. This finding suggested that methacholine challenges could interfere with the effects of $\mathrm{NO}_{2}$. The argument has been corroborated a posteriori by the observation that the changes in $\mathrm{LTB}_{4}$ and $\mathrm{PGD}_{2}$ after $\mathrm{NO}_{2}$ exposure were in a similar range as those measured after methacholine inhalation. Omitting methacholine challenges enabled us to perform bronchoscopy within one hour after the end ( $4 \mathrm{~h}$ after the beginning) of exposure, and to measure the initial changes induced by $\mathrm{NO}_{2}$. The functional effects of $\mathrm{NO}_{2}$ do occur within one hour after exposure $[1,20,22,23]$.

There was only a small exercise-induced fall in FEV after the first exercise period, which was equal for filtered air and $\mathrm{NO}_{2}$ exposure and virtually vanished during the repeated exercise periods, presumably due to refractoriness (fig. 1). Since our study was not designed to investigate changes of exercise-induced bronchoconstriction $[22,24]$, these observations have to be interpreted cautiously. Nevertheless, they suggest that $\mathrm{NO}_{2}$ did not enhance exercise-induced asthma within the repeated tests or diminish refractoriness.
The results of our baseline lavages in asthmatic and healthy individuals are generally in line with the findings that the asthmatic disease is accompanied by distinct inflammatory processes [6]. The fact that airway inflammation has been demonstrated even in newly diagnosed asthma [26] suggests that an inflammatory cell response is a sensitive indicator of the disease activity. We studied whether short-term exposure to $\mathrm{NO}_{2}$ could reveal alterations of the inflammatory cell pattern and mediator profile which would fit the higher susceptibility to $\mathrm{NO}_{2}$ of asthmatic compared to normal subjects.

In the BALF of asthmatic subjects, we found decreased levels of 6-keto-PGF ${ }_{1 \alpha}$, (a metabolite of $\left.\mathrm{PGI}_{2}\right)$ and increased levels of $\mathrm{TxB}_{2}$ (a metabolite of $\mathrm{TxA}_{2}$ ) and $\mathrm{PGD}_{2}$ after $\mathrm{NO}_{2}$ compared to filtered air exposure, whereas the concentrations of $\mathrm{PGE}_{2}, \mathrm{PGF}_{2 \alpha}$ and histamine did not change. There was a tendency for leukotrienes $\left(\mathrm{LTB}_{4}, \mathrm{C}_{4}, \mathrm{D}_{4}\right.$, $\mathrm{E}_{4}$ ), in single subjects, to show increased levels after $\mathrm{NO}_{2}$ exposure compared to filtered air exposure and baseline bronchoscopy. These data can be interpreted as an increase in inflammatory mediators, which are associated with bronchoconstriction $\left(\mathrm{PGD}_{2}, \mathrm{TxB}_{2}\right)$, and a decrease in a mediator which is associated with bronchodilation $\left(6-\right.$ keto-PGF $\left._{1 \alpha}\right)$. Since it is known that increased levels of $\mathrm{PGD}_{2}$ and $\mathrm{LTE}_{4}$ are related to enhanced bronchial responsiveness, our observations would be consistent with the previous findings that airway responsiveness in humans can be enhanced by $\mathrm{NO}_{2}$. The slight increase of $\mathrm{TxB}_{2}$ in the healthy controls suggests that breathing 1 ppm $\mathrm{NO}_{2}$ (about one fifth of the workplace threshold value) is not completely without effect even in normal subjects. On average, marked bronchoconstriction was not observed in our study. Therefore, the observed changes are attributed to the ability of $\mathrm{NO}_{2}$ to induce proinflammatory changes, the functional consequences of which could not be detected within our protocol. The changes in mediators indicate an activation of cells and support the idea that asthmatic subjects are more susceptible to $\mathrm{NO}_{2}$ than normals. In addition, changes in inflammatory mediators seem to precede cellular changes or to be more sensitive to the effects of $\mathrm{NO}_{2}$ than cell numbers.

Our results are, at least partially, compatible with those from animal in vivo and in vitro studies. Exposure of rat alveolar macrophages to $\mathrm{NO}_{2}$ in vitro resulted in an increase of $\mathrm{LTB}_{4}$ production [27]. Rabbits showed a decrease of 6-keto-PGF ${ }_{1 \alpha}$ after breathing $10 \mathrm{ppm} \mathrm{NO}_{2}$, while $\mathrm{TxB}_{2}$ was elevated after $1 \mathrm{ppm}$ and depressed after 3 and $10 \mathrm{ppm} \mathrm{NO}_{2}$ [28]. Similarly, in rats, the level of 6-keto-PGF la $_{1 \alpha}$ decreased [29]. The concentration of $\mathrm{TxB}_{2}$ was elevated after 5 days of exposure; in contrast, the levels of $\mathrm{PGF}_{2 \alpha}$ and $\mathrm{PGE}_{2}$ first decreased, transiently increased, and then decreased again. In sheep, increases in $\mathrm{LTB}_{4}$ and $\mathrm{LTE}_{4}$ in BALF between 0.5-24 $\mathrm{h}$ after exposure have been demonstrated, although at very high concentrations of $\mathrm{NO}_{2}$ [30]. These results indicate quite a complicated time course, which depends on exposure levels, and support the view that the effects of prolonged or repeated exposures to $\mathrm{NO}_{2}$ cannot be derived from short-term exposure results [31-33].

In previous studies, bronchoscopy has been applied in healthy individuals to detect changes in BALF induced 
by $\mathrm{NO}_{2}$. In these studies, investigators focused on parameters which were more likely to reveal an oxidative damage from $\mathrm{NO}_{2}$ in healthy subjects, and none of them has investigated asthmatic subjects. The activity of the $\alpha_{1}$-proteinase inhibitor has been found to be decreased after exposure to 3-4 ppm [34], but not $1.5 \mathrm{ppm} \mathrm{NO}$ [35]; the level of the antiprotease $\left(\alpha_{2}\right.$-macroglobulin) increased after exposure to $0.6 \mathrm{ppm} \mathrm{NO}_{2}$ [36]. In contrast to our results in the healthy control group, an increased number of BAL neutrophils has been observed in the bronchial washing fraction about one day after exposure to $2 \mathrm{ppm} \mathrm{NO}_{2}$ [37], and the number of mast cells and lymphocytes was elevated in a dose-dependent manner $24 \mathrm{~h}$ after breathing 2.25 to $5.5 \mathrm{ppm} \mathrm{NO}_{2}$ [38], and 4,8 and $24 \mathrm{~h}$, but not $72 \mathrm{~h}$ after exposure to $4 \mathrm{ppm} \mathrm{NO}_{2}$ [39]. These discrepancies are probably due to the differences in $\mathrm{NO}_{2}$ concentrations and time intervals between exposure and lavage.

Our data indicate that subjects with asthma as well as healthy subjects do not show significant alterations of BAL cellular composition one hour after the end of $\mathrm{NO}_{2}$ exposure. Whereas this result is in accordance with some of the studies performed in healthy subjects [34-36], it does not agree with the increase in the number of mast cells and lymphocytes reported by SANDSTRÖM and coworkers $[38,39]$. The discrepancy is probably due to the fact that these authors performed lavage $24 \mathrm{~h}$ and not one hour after exposure to higher levels of $\mathrm{NO}_{2}$. The significant decrease in the number of eosinophils in asthmatic subjects, both after filtered air and $\mathrm{NO}_{2}$ exposure as compared to baseline lavage, has to be attributed to the effects of the prolonged exercise protocol. After exercise-induced bronchoconstriction, elevated numbers of BALF eosinophils have been reported [40]. However, it is unclear whether these results also apply to exercise per se in the absence of exercise-induced bronchoconstriction, and to repeated exercise tests.

The macroscopic appearance of the airways is rarely used to describe stimulus-related effects, probably due to the difficulties in quantitating visual impression. Using a simple scoring system [10], we found that $\mathrm{NO}_{2}$ caused, on average, an increase in erythema, oedema and friability. Clearly, these changes are not only associated with cellular infiltration but also with permeability, water flux and other parameters, which we did not measure.

Most of the functional data suggest that threshold levels of $\mathrm{NO}_{2}$ which cause "latent" changes in the airways that can only be detected by assessment of airway responsiveness are lower than those levels which induce "apparent" changes, such as impairment of lung function. An increase in airway responsiveness could be interpreted as an indicator (although not unique) of inflammatory changes induced by $\mathrm{NO}_{2}$. This interpretation is in line with present knowledge on the asthmatic disease [6], and with the parallelism that has been demonstrated between an increase in airways responsiveness and inflammatory changes, for example, by ozone [41].

Although it is not possible to evaluate the clinical implications of the changes in inflammatory mediators which we have observed, their presence and consistency suggest that $\mathrm{NO}_{2}$ exposure could lead to potential adverse effects at this level. Adverse effects at low levels of $\mathrm{NO}_{2}$ have been shown by epidemiological studies [42]. The level of nitrogen dioxide exposure chosen in the present study falls within peak exposure limits which can be reached or exceeded under indoor and outdoor exposure conditions, although not regularly encountered [43]. Furthermore, due to mouthpiece breathing, the effective dose of $\mathrm{NO}_{2}$ may have been slightly higher than in unencumbered breathing at the same ambient concentration. Despite this, data interpretation may benefit from our finding that exposure to a burden of $3 \mathrm{ppm}^{*} \mathrm{~h}$ of $\mathrm{NO}_{2}$ is capable of influencing inflammatory mediators in subjects with asthma, without producing obvious changes in lung function or symptoms.

In summary, we have demonstrated that short-term exposure to $1 \mathrm{ppm} \mathrm{NO}_{2}$ was capable of inducing or enhancing inflammatory changes in the airways of asthmatic but not healthy subjects. These changes were small but consistent. As we failed to reveal consistent $\mathrm{NO}_{2}$ induced effects on lung function, we would like to suggest that short-term exposure studies could benefit from bronchoscopic techniques, in order not to miss effects on airway cellular function which could be relevant for long-term exposures.

\footnotetext{
Acknowledgements. The authors gratefully acknowledge the skilful technical assistance of S. Koschyk and K. Templin, and wish to thank the subjects for their kind co-operation in this study and K.F. Rabe for helpful discussions. They are also grateful to the Environmental Protection Agency of Hamburg for their support in gas calibration.
}

\section{References}

1. Mohsenin V. Airway responses to $2.0 \mathrm{ppm}$ nitrogen dioxide in normal subjects. Arch Environ Health 1988; 43: 242-246.

2. Hazucha MJ, Ginsberg JF, McDonnell WF, et al. Effects of $0.1 \mathrm{ppm}$ nitrogen dioxide on airways of normal and asthmatic subjects. J Appl Physiol 1983; 54: 730-739.

3. Orehek J, Massari JP, Gayard P, Grimaud C, Charpin J. Effect of short-term, low-level nitrogen dioxide exposure on bronchial sensitivity of asthmatic patients. J Clin Invest 1976; 57: 301-307.

4. Ahmed T, Marchette B, Danta I, et al. Effect of 0.1 ppm $\mathrm{NO}_{2}$ on bronchial reactivity in normals and subjects with bronchial asthma. Am Rev Respir Dis 1982; 125 (Suppl. 2): 152 (Abstract).

5. Kleinman MT, Baily RM, Linn WS, et al. Effect of 0.2 ppm nitrogen dioxide on pulmonary function and response to bronchoprovocation in asthmatics. J Toxicol Environ Health 1983; 12: 815-826.

6. Barnes PJ, Rodger IW, Thomson NC (eds). Asthma: Basic Mechanisms and clinical management. 2nd edn, London, Academic Press, 1992.

7. National Institutes of Health/National Asthma Education Program. Guidelines for the diagnosis and management of asthma. US Department of Health and Human Services. NIH Publication No. 91-3042, 1991.

8. Quanjer $\mathrm{PhH}$ (ed.). Standardized lung function testing. Eur Respir J 1993; 6 (Suppl. 16): 5-40. 
9. NIH, NHLBI and NIAID, AAAI, ACCP, and ATS. Workshop summary and guidelines: investigative use of bronchoscopy, lavage, and bronchial biopsies in asthma and other airway diseases. J Allergy Clin Immunol 1991; 88: $808-814$

10. Thompson AB, Daughton D, Robbins RA, Ghafouri MA, Oehlerking M, Rennard SI. Intraluminal airway inflammation in chronic bronchitis. Am Rev Respir Dis 1989; 140: 1527-1537.

11. Nowak D, Grimminger F, Jörres R, et al. Increased $\mathrm{LTB}_{4}$ metabolites and $\mathrm{PGD}_{2}$ in $\mathrm{BAL}$ fluid after methacholine challenge in asthmatic subjects. Eur Respir J 1993; 6: 405-412.

12. Grimminger F, Menger M, Becker G, Seeger W. Potentiation of leukotriene production following sequestration of neutrophils in isolated lungs: indirect evidence for intercellular leukotriene $\mathrm{A}_{4}$ transfer. Blood 1988; 72: 1687-1692.

13. Grimminger F, Becker G, Seeger W. High yield enzymatic conversion of intravascular leukotriene $\mathrm{A}_{4}$ in bloodfree perfused lungs. J Immunol 1988; 141: 2431-2436.

14. Powell W. High pressure liquid chromatography of eicosanoids. In: Lands WEM, ed. Biochemistry of Arachidonic Acid Metabolism. Boston, Martinus Nijhoff Publishing, 1985.

15. Schulz R, Seeger W. Release of leukotrienes in the perfusate of calcium-ionophore stimulated rabbit lungs: influence of 5-lipoxygenase inhibitors. Biochem Pharmacol 1986; 35: 183-193.

16. Jobson JD. Applied multivariate data analysis. Vol. I. Regression and experimental design. New York, SpringerVerlag, 1991.

17. Hartung J. Statistik. München, Oldenbourg Verlag, 1985.

18. Linn WS, Shamoo DA, Avol EL, et al. Dose-response study of asthmatic volunteers exposed to nitrogen dioxide during intermittent exercise. Arch Environ Health 1986; 41: 292-296.

19. Morrow PE, Utell MJ. Responses of susceptible subpopulations to nitrogen dioxide. Res Rep Health Eff Inst 1989; 23: 1-45.

20. Bylin G, Hedenstierna G, Lindvall T, Sundin B. Ambient nitrogen dioxide concentrations increase bronchial responsiveness in subjects with mild asthma. Eur Respir J 1988; 1: 606-612.

21. Mohsenin V. Airway responses to nitrogen dioxide in asthmatic subjects. J Toxicol Environ Health 1987; 22: 371-380.

22. Bauer MA, Utell MJ, Morrow PE, Speers DM, Gibb FR. Inhalation of $0.30 \mathrm{ppm}$ nitrogen dioxide potentiates exercise-induced bronchospasm in asthmatics. Am Rev Respir Dis 1986; 134: 1203-1208.

23. Jörres R, Magnussen H. Airways response of asthmatics after a $30 \mathrm{~min}$ exposure, at resting ventilation, to 0.25 ppm $\mathrm{NO}_{2}$ or $0.5 \mathrm{ppm} \mathrm{SO}_{2}$. Eur Respir J 1990; 3: 132-137.

24. Jörres R, Magnussen H. Effect of $0.25 \mathrm{ppm}$ nitrogen dioxide on the airway response to methacholine in asymptomatic asthmatic patients. Lung 1991; 169: 77-85.

25. Rubinstein I, Bigby BG, Reiss TF, Boushey HA Jr. Shortterm exposure to $0.3 \mathrm{ppm}$ nitrogen dioxide does not potentiate airway responsiveness to sulfur dioxide in asthmatic subjects. Am Rev Respir Dis 1990; 141: 381-385.

26. Laitinen LA, Laitinen A, Haahtela T. Airway mucosal inflammation even in patients with newly diagnosed asthma. Am Rev Respir Dis 1993; 147: 697-704.

27. Robison TW, Duncan DP, Forman HJ. Chemoattractant and leukotriene $\mathrm{B}_{4}$ production from rat alveolar macro- phages exposed to nitrogen dioxide. Am J Respir Cell Mol Biol 1990; 3: 21-26.

28. Schlesinger RB, Driscoll KE, Gunnison AF, Zelikoff JT. Pulmonary arachidonic acid metabolism following acute exposures to ozone and nitrogen dioxide. J Toxicol Environ Health 1990; 31: 275-290.

29. Kobayashi T. Effects of nitrogen dioxide exposure on the contents of prostaglandins and thromboxane $\mathrm{B}_{2}$ in bronchoalveolar lavage. Prostaglandins 1986; 31: 469475.

30. Fitzpatrick TM, Guimont JA, Mayorga MA, Januszkiewicz AJ. Effects of nitrogen dioxide exposure on leukotriene concentration in sheep bronchoalveolar lavage fluid. $\mathrm{Am}$ Rev Respir Dis 1993; 147 (Suppl. 2): A72 (Abstract).

31. Rubinstein I, Reiss TF, Bigby BG, Stites DP, Boushey HA. Effects of $0.60 \mathrm{ppm}$ nitrogen dioxide on circulating and bronchoalveolar lavage lymphocyte phenotypes in healthy subjects. Environ Res 1991; 55: 18-30.

32. Sandström T, Helleday R, Bjermer L, Stjernberg N. Effects of repeated exposure to $4 \mathrm{ppm}$ nitrogen dioxide on bronchoalveolar lymphocyte subsets and macrophages in healthy men. Eur Respir J 1992; 5: 10921096.

33. Magnussen H. Experimental exposures to nitrogen dioxide (Editorial). Eur Respir J 1992; 5: 1040-1042.

34. Mohsenin V, Gee JBL. Acute effect of nitrogen dioxide exposure on the functional activity of $\alpha_{1}$-protease inhibitor in bronchoalveolar lavage fluid of normal subjects. Am Rev Respir Dis 1987; 136: 646-650.

35. Johnson DA, Frampton MW, Winters RS, Morrow PE, Utell MJ. Inhalation of nitrogen dioxide fails to reduce the activity of human lung alpha-1-proteinase inhibitor. Am Rev Respir Dis 1990; 142: 758-762.

36. Frampton MW, Finkelstein JN, Roberts NJ Jr, Morrow PE, Utell MJ. Effects of nitrogen dioxide exposure on bronchoalveolar lavage proteins in humans. Am J Respir Cell Mol Biol 1989; 1: 499-505.

37. Devlin R, Horstman D, Becker S, Gerrity T, Madden M, Koren $\mathrm{H}$. Inflammatory response in humans exposed to 2.0 ppm $\mathrm{NO}_{2}$. Am Rev Respir Dis 1992; 145 (Suppl. 2): A456 (Abstract).

38. Sandström T, Stjernberg N, Eklund A, et al. Inflammatory cell response in bronchoalveolar lavage fluid after nitrogen dioxide exposure of healthy subjects: a doseresponse study. Eur Respir J 1991; 4: 332-339.

39. Sandström T, Andersson MC, Kolmodin-Hedman B, Stjernberg N, Ångström T. Bronchoalveolar mastocytosis and lymphocytosis after nitrogen dioxide exposure in man: a time-kinetic study. Eur Respir J 1990; 3: $138-143$

40. Crimi E, Balbo A, Milanese M, Miadonna A, Rossi GA, Brusasco V. Airway inflammation and occurrence of delayed bronchoconstriction in exercise-induced asthma. Am Rev Respir Dis 1992; 146: 507-512.

41. Seltzer J, Bigby BG, Stulbarg M, $\mathrm{H}$ et al. $\mathrm{O}_{3}$-induced change in bronchial reactivity to methacholine and airway inflammation in humans. J Appl Physiol 1986; 60: 1321-1326.

42. Braun-Fahrländer $\mathrm{C}$, Ackermann-Liebrich U, Schwartz J, Gnehm HP, Rutishauser M, Wanner HU. Air pollution and respiratory symptoms in preschool children. $\mathrm{Am}$ Rev Respir Dis 1992; 145: 42-47.

43. Berglund M. Health risk evaluation of nitrogen oxides. 2. Exposure. Scand J Work Environ Health 1993; 19 (Suppl. 2): 14-20. 